\title{
Marketing Adult Education for Megaprojects in the Northwest Territories
}

\author{
Andrew P. Hodgkins, University of Alberta \\ hodgkins@primus.ca
}

\begin{abstract}
This empirical research inquiry examines the influence that the current economic climate - driven by the extraction of non-renewable resources currently underway in the Northwest Territories - is having on adult education policy and program development. A qualitative methodology involving open-ended interviews was chosen for this study to better understand how local realities of labour market influenced educational policy and its implications for policy process and practice. The inquiry gathers perceptions of those given authority and responsibility for developing policy on behalf of northerners, and also those affected by such policies. Interviews were conducted during the summer of 2005 and included policy planners at Aurora College and other stakeholders involved in northern development, adult education and training. Findings suggest that the cooptation of adult education by market forces has occurred despite increased local autonomy through recent Aboriginal self-governance initiatives. Implications for community sustainability and governance are examined within this context.
\end{abstract}

\section{Introduction}

Today's economic developments in the Northwest Territories (NWT) dwarf all previous activity in the region. Since their discovery in the mid 1990's, diamond exports have surged threefold, trailing only Botswana and Russia in global production (Burleton, 2003). The resurgence of oil and gas development as seen by the impending Mackenzie Gas Project has also sparked a similar optimistic climate, with forecasters predicting a multibillion dollar project in the works that will see gas piped from the Mackenzie Valley to southern locales - making it the longest pipeline of its kind in the world (Mackenzie Gas Project, n.d.).

In response to these heady forecasts and ripe economic climate, financial and business analysts warn that the rise of megaprojects to the region must be accompanied by increased development of both physical and human resources before the North's bounty of riches can be fully tapped. For instance, a Toronto Dominion Bank Financial Report (Burleton, 2003), entitled: "Canada's Northwest Territories: Can Gas and Gems Bring Sustained Growth to the North?" which was circulated amongst personnel at Aurora College warns that a labour shortage due to "a lack of skilled workers" will hamper the region's progress - a problem "exacerbated by low rates of educational attainment among the Aboriginal population." Increased provision for education is recommended, with additional funding resting on the shoulders of the territorial government (GNWT).

Accompanying the economic boom are political changes that have resulted in increased decentralization of power in the territory. Most notably, devolution and

Journal of Contemporary Issues in Education, 2008, 3(2), pp. 46-58.

ISSN 1718-4770 (C) 2008 University of Alberta

http://ejournals.library.ualberta.ca/index.php/JCIE 
resource sharing agreements between the federal government, GNWT, and Aboriginal groups is occupying much of the political discourse, as each group vies for political and economic control over resources.

Presently four of six Aboriginal groups have signed land claims agreements with the federal government - agreements that include land entitlement, cash payments, and in some cases control over subsurface rights. In December, 2004 the Tlicho people who live in four communities north of the Great Slave Lake, with an estimated population of 2,893 (Northwest Territories Bureau of Statistics, 2005a), settled a land claim and self government agreement which gives them control over 39,000 square kilometers of territory, access to $\$ 152$ million paid over 15 years and a share in resource royalties. Meanwhile, the Akaitcho and Dehcho people have not signed an agreement - a source of contention for both the federal and territorial governments which are caught between two competing interests: settling land claims so that an attractive investment climate can be created, while at the same time vying with the Dene for a percentage of the resource royalties that is expected to be generated from megaprojects (Neary, 2006).

These negotiations are occurring at a time when the Aboriginal population is becoming better educated, more mobile, and taking greater control of education at the local level. While high school graduation rates for this sector of the population have doubled in the past decade (Northwest Territories Bureau of Statistics, 2006), there has been a demographic shift away from smaller, largely Aboriginal communities to larger centers such as Yellowknife where job prospects are better. This urbanization trend is supported by statistics. In the past thirty years the population of Yellowknife increased from $28.6 \%$ of the territorial population in 1976 to $45.2 \%$ in 2005 (Northwest Territories Bureau of Statistics, 2006). With approximately half the population of the NWT, Yellowknife is one of the few communities where the majority of its citizens are nonAboriginal.

Not surprisingly, rapid changes to the territory have also captured the interest of the academic community who see an important opportunity to conduct research that is both timely and relevant to the needs of northerners. The Arctic Human Development Report (AHDR) recently recognized the need to support research that monitors ongoing changes. Published in 2004, the report was described as "the first comprehensive assessment of human well-being that covers the entire Arctic region" (p. 3). According to the report, no assessment of northern education can be made "partly because there is very little circumpolar research in the field" (p. 169). The report goes on to state, "Education policy is driven by values and interests. It is therefore important to know if some take precedence in curriculum development over others, and why" (p. 169).

This empirical research inquiry attempts to shed light on the question of educational values and interests posed by the AHDR by examining the influence that the current economic climate, driven by the extraction of non-renewable resources currently underway in the NWT, are having on adult education policy and program development. Specifically, the study endeavours to better understand how local realities of labour market influenced educational policy and its implications for policy process and practice from the voices of those given authority and responsibility for developing policy on behalf of northerners, and also those affected by such policies. The study is premised within the wider post-development and globalization debate regarding the perceived intellectual and economic influence of powerful multinational corporations in policy 
related issues, and the perceived intellectual dependency of those given responsibility for social policy in the NWT. Connected to this work are theoretical considerations that examine the intersection of globalization and development on northern indigenous communities, particularly in the context of new frameworks of economic and political governance.

Marxian theories of state formation and hegemony developed by Antonio Gramsci (1891-1937) provide a useful framework for understanding the manner in which postsecondary institutions have positioned themselves with respect to the pressure of resource development. Within this framework, aspirations of the state are closely aligned with those of the market: Values of the market must permeate civil society in order for the ruling class - whose interests are orchestrated through the state - to maintain its position of control. For Gramsci, divisions between the state and civil society are in fact illusory - an illusion that must be maintained in order for the state to exist (Gramsci, A. 1971/1992, pp. 206-270). As Andy Green (1990) puts it, "The state works through civil society since one of its primary functions is to mould and educate society at all levels in conformity with its own historical goals" (p. 93).

This explanation of the modern state introduces us to the nature in which power operates within it. According to Green (1990),

A hegemonic order represents a temporary settlement, the ideological balance of force of the ruling class, not the homogenous substance of an imposed class ideology. It is won through continual conflict which involves the creation of alliances, the attempted incorporation of subordinate groups and, even, the granting of concessions so long as these do not damage the vital interests of the dominant group. (p. 94)

Gramsci's theories of state formation and hegemony have been used by some theorists (Cunningham, 2000; Mayo, 1999; Murphy, 2001) to understand the present commodification of adult education. These theorists argue that adult educators face a moral dilemma of choosing to either serve the needs of the market through provision of vocational training, or instead strengthen civil society through education promoting the development of a critical consciousness. In order to restore balance to society, educators must actively take steps towards redressing the historical and ideological forces that have increasingly lead to locating their practice within the realm of the market. It is in the realm of civil society - in what Peter Mayo (1999) describes as a "vast and amorphous arena of struggle" (p. 6) - that create possibilities for restoring principles of democratic governance through transformative, counter hegemonic education.

\section{Method}

Aurora College provides the logical focal point for this study as the college plays an important role in education, training and employment for many northern students - the majority of whom are Aboriginal. As the unofficial training arm of the GNWT, the college mandate is to deliver community-centered postsecondary programs in preparation for the northern labour market. 
Primary data were collected through semi-structured interviews and informal discussions held with respondents and other key informants. Formal interviews occurred during the first two weeks of July 2005; informal visits to Fort Smith occurred in March and July 2006. These visits provided a means of grounding information gathered within the context in which it was shared. Regular correspondence also occurred during the course of the study, providing yet another means of triangulating findings.

\section{Data Collection}

Apart from college personnel, representatives from industry, Aboriginal groups, and academia were also interviewed. Given the diverse array of stakeholders, interview questions were designed to draw out tensions and incongruities between competing interests. In doing so, critical deliberation of the research question occurred.

A total of eight interviews ( 4 men; 4 women) were conducted. College personnel $(n=5)$ interviewed comprised policy and program planners at two regional campuses (Yellowknife and Inuvik) and the head office in Fort Smith. These included 3 male and 2 female respondents - one of which is Aboriginal. Non-college respondents $(n=3)$ included 2 female and 1 male respondent - one of which is Aboriginal.

College interviews occurred at both the Inuvik and Yellowknife regional campuses, and the head office in Fort Smith. Interviews were held in respondents' offices and lasted no longer than one hour. Non-college interviews occurred in Yellowknife.

Interview formats varied between college and non-college interviews. College interviews were semi-structured, involving a total of 8 open-ended questions. This format was chosen as a means of maximizing input from respondents, while at the same time, maintaining a level of uniformity so that cross comparison with other college personnel during the analysis stage of the investigation could occur. Unlike the college interviews, a set of pre-established questions was not used for the other respondents. Instead, an unstructured interview format was employed as it better suited the diversity of respondents' expertise and interests.

\section{Data Analysis}

An iterative inductive analysis described by Huberman and Miles (1998) provided an effective means to mesh findings within the overall theoretical framework. In this model, a series of question and answer cycles drives data analysis, resulting in subsequent refinement and modification of understanding as new constructs emerge and findings are validated. Concomitantly, abstract generalizations form from empirical data gathered ( $\mathrm{p}$. 187).

\section{Results}

Two general categories relating to the central research question have been identified from an analysis of interview transcripts: 1) Community Relations: Meeting high expectations of various stakeholders within a shifting socio-political dynamic; and 2) Marketization of Adult Education: Politics, Priorities, and Partnerships. These categories serve as central 
nuclei for key issues shared by respondents to be clustered into. In the first category, multiple perspectives involving community relations and adult education are shared. The second category examines the manner in which partnerships impact funding for programs, and how these policies are perceived as shaping notions of community sustainability.

\section{College Mandate and Community Needs}

College respondents cited labour market training as the college mandate's main objective. One respondent stated the college mandate is to create better lives for northerners.

That means doing whatever communities require to give students/graduates the tools to choose employment of their liking, and to be able to support their families and be able to afford the choices that they'd like to give them a good quality of life.

Another respondent matter-of-factly asserted: We train people for jobs and that's always been the case - we started out as a vocational centre and we still have a large arm of the college that trains for industry.

Impacting the college mandate are tight fiscal constraints and uncertain funding, as low formal educational levels amongst the majority of its students have caused resources to be redirected towards upgrading rather than postsecondary programs. Given these constraints and realities, resources are spread thin. As one respondent stated, the college tries to be responsive and perhaps too responsive in the sense that it goes in all directions at once. This frustration was summed up by another respondent:

I think it is a challenge for the college to work in an environment that is so hugehaving 3 campuses, 23 learning centres. How do you keep one standard up? And how do you deliver every program under the sun that every person wants when you have a limited amount of funding? You have to be all things to all people and it's a hard role to fill.

A frustration cited by college respondents involves high expectations by stakeholders for the college to offer both upgrading and postsecondary programming. Considering the college spends $30 \%$ of its programming budget (Government of the Northwest Territories, n.d.) on Adult Basic Education (ABE) - it is not surprising that it has the dual role as both an upgrading centre and a certificate, diploma and degree granting institution, which creates tensions that are experienced at both a philosophical and fiscal level. According to one college respondent:

Sometimes people in the communities have had only the first few grades of schooling because of the residential school problems, and people had to leave the community; it was very difficult. And so people would leave and go back home; a couple of generations that have missed getting real literacy. And so there's a real struggle out there, and we are struggling to figure out how to satisfy that. 
One college employee informally shared a theory as to the cause of low education levels in communities, explaining that the GNWT - in its zeal to remove northern residential schools and decentralize the school system - never filled the vacuum by adequately funding local schools. The end result: Education was brought to the people but at a cost of being under-funded, resulting in even lower levels of formal education than had existed under the residential school system when resources were centralized (personal communication, March 20, 2006). Another respondent stated: The government has tried to address high school education in the communities by making access to $A B E$...you just wonder what that is all about because one teacher can't teach all subject areas...we have large expectations.

Consequently, there is a perception that government policy at the primary and secondary levels has undermined efforts by those charged with the responsibility of implementing policy at the postsecondary level. These insights which indicate centralized government policy, which has been historically resisted as a colonially imposed measure, are cited by policy planners themselves as undermining their efforts.

\section{Student Success}

Despite measures to encourage student success, one college respondent lamented:

Eighty percent of our students are Aboriginal; 20\% of our graduates are Aboriginal. They fall in the cracks somewhere. They do not gain success; they do not finish programs. We are failing them somewhere, which is an incredible statistic.... Why aren't people finishing programs? And a lot of our students whether Aboriginal or not have families when they come here, but a lot of nonAboriginal people are younger when they start. The choice for a lot of Aboriginal women is they get pregnant and have their children first and then they decide to come back to school. And then they have these huge responsibilities, and it is a lot harder for them to get through.

\section{Recruitment}

The degree to which megaprojects have impacted enrolment in adult education was discussed by respondents. Respondents at one campus cited megaprojects as being a "catalyst" in generating interest to return to school. As one respondent stated: I've seen people in that [Natural Resources Technology] program that maybe five years ago I wouldn't have seen...I think that a lot of this has to do with the potential they're seeing in industry. Another respondent added:

For me one of the best things about this potential [Mackenzie Valley] pipeline is that it's ramping up the interest, the energy, the hope for northerners to be truly a meaningful part of the future. In the communities the hopelessness and social issues are the biggest things to deal with. In my view, let's go full bore ahead because it's going to take us five years to have a journey person out there; let's start today. Industry is a catalyst. At the end there will be something. It may not 
be exactly what is painted in that proposal, but they will have something at the end of the day that they didn't have today: They'll have those safety tickets, so people can go wherever they want in Canada. How many people are away from this community in the trades area? I'd say 85 to $90 \%$. Why is that?

Conversely, a respondent at a different campus stated: The challenge is that there's a lot of employment in the North, and so they take jobs rather than get their education - so that's our on-going challenge. A different respondent added: We have the money, but ironically most of them are working...those that aren't have issues that impede them. A non-college respondent supported these claims by stating:

Everybody that can be employed or easily trained is already out there on the ground, and the next group of people that can get into mines actually require extra effort because they have learning barriers - so they may be FAS [Fetal Alcohol Syndrome] kids, or a people that are chronically unemployed, specific learning challenges and needs.

Notions that the labour market is currently saturated with northern workers were countered by an industry representative, who stated:

There is a large untapped resource of Aboriginal people in the NWT. The problem is that many are under-qualified for the jobs in the increasingly high tech mining industry. The GNWT is responsible for education here. Perhaps it is time they were asked what their strategy is to significantly increase the number of high school graduates. GNWT should be asked about its strategy to increase support for trades training. NWT Mining and Petroleum are booming but programs need to be in place now to ensure Northerners can take advantage. Hiring targets alone won't do it. Industry needs the raw material - Grade 12 grads at minimum.

Program Development and Funding

The degree to which recent megaprojects have impacted college programming was shared by one respondent this way:

We haven't really shifted our emphasis, but we've expanded our programs in response to industrial development. We don't do all the training, but a lot of it as a result of the funding.

The majority of third-party funding for industrial programs comes from the Aboriginal Skills and Employment Program (ASEP). ASEP comprises a three year, 12 million dollar allocation, which according to the federal government, represents a "commitment to work with Aboriginal groups and other stakeholders to provide high quality, culturally relevant education for Aboriginal learners, to help them to achieve their educational needs and aspirations" (Human Resources and Social Development Canada, 2005).

ASEP funds are controlled by the Petroleum Operators Training Committee (oil and gas training) and the Mine Training Society (mining). These societies are composed of members of Aboriginal groups, GNWT (Aurora College), and industry. Their mandate 
is to increase participation of Aboriginal northerners in existing (diamond mines) and future (oil and gas) megaprojects. As one college respondent explained, In response to ASEP funding- that's where we get the ideas to decide what programs we're going to deliver.

Ironically, ASEP funding is also cited as complicating matters for policy planners, owing to the parameters in which it is allocated. In light of pressure to hire Aboriginal northerners, programs have become highly politicized to the point that ethnicity is the deciding factor when it comes to offering vocational based training related to megaprojects. As one respondent lamented:

We'd offer more for industrial training...but not enough people...there are those that are not Aboriginal...ASEP funding precludes them...our funding is based on the number of Aboriginals in the program. We have to break even. If we don't get enough Aboriginals, we don't run it.

Learner Needs as Contested Sites

Formation of partnerships with industry raises the thorny question of who represents community interests, and how such representation translates into learner needs and program choice. As one non-college respondent whose community is directly impacted by the Mackenzie Gas Project explained, megaprojects have created a divide between the interests of leaders and its people:

There are so many people in the communities that are against the gas project but they do not want to speak out against it because of the repercussions they would get from their Aboriginal leadership, because standing up against the pipeline would mean they would not be getting jobs from the band office; they'd be blackballed essentially and discredited... some leadership want to hear from the people - we are not tarring them all with the same brush; people need to know that it is alright to ask their leadership about the project. For the leadership, they see their people without any jobs - they see the young people hanging out at the band office waiting for a job to come through, and they want to help those people legitimately - and so they see the pipeline as the only opportunity - but there has to be an informed decision.

Similar concerns have also been raised during environmental panel hearings for the proposed Mackenzie Gas Project. According to one report, "Discord exposed within the Gwich'in nation" (King, February, 27, 2006), a divide exists between elders and youth who are against the project, and Aboriginal leaders who endorse it. One elder's concern related to youth being unable to gain meaningful employment: "Nobody's got education...so how will you train people in two years?" In response, industry proponents cited its working relationship with the college to identify potential workers. Another elder opposed the project, stating it will "worsen the social, cultural, physical, and spiritual well-being of our communities" (A13). Still other elders in the region feel megaprojects have eclipsed and hence silenced alternatives encouraging cottage-based 
enterprises focused on renewable resources - a move that could diversify the economy and foster self-sufficiency (Loreen, 2005).

Such "divide and rule" discord has implications for policy aimed at adult education and training. As the following non-college respondent explains, limited options for adult learners in small communities may be linked to the current economic boom:

A lot of times these young people are not interested in these types of jobs - there's only a certain number and types of jobs available, and only for mainly men, and a lot of people are not interested in these physical labour jobs ... and there's no other stream being offered to them.... The construction jobs being offered are not the end-all for people that they want to accept. I feel a lot of them want to get out of the communities and get postsecondary education, and that's not really being encouraged right now because the labour force that is needed is young, skilled trades. You look at the political situation: We need young Aboriginal people to develop leadership. In my own family and a lot of other Dene families education is really stressed so that our culture would survive and we'd maintain our traditions - but right now a lot of the families and young people are encouraged to go and get their training and make money - fast money. Some of them will be able to take advantage of this short-term work and save the money to go on to school. But the question is how many people will do that, and how many will get stuck or pulled into the working lifestyle rather than going on to postsecondary education.... We're hearing from a lot of young people that they want more options to be generated, and more long term thinking.

As the results illustrate, new frameworks of economic and political governance in the Northwest Territories have exacerbated competing notions regarding the role of adult education amongst stakeholders. Far from being a uniform account of northern development, perceptions shared by respondents are fraught with tensions which occur on multiple and diffused platforms. Rather than acting in isolation, tensions interact synergistically to shape the present context. For example, competition for resource royalties (tensions between governments) has lead to Aboriginal groups signing separate agreements with industry (tension between governments and industry). In turn, balkanization of Aboriginal groups leads to tensions at the local level, as seen in rifts arising between an emerging comprador elite and tribal members concerning notions of community sustainability.

\section{Discussion}

If we recall the Arctic Human Development Report's call to understand "values and interests" driving education in the North, then perceptions shared by respondents are especially relevant. While "values and interests" expressed by college and industry respondents are resoundingly clear: to get as many Aboriginal northerners employed in emerging industries, the manner in which these values and interests impact, shape, and arguably deform holistic strategies towards notions of community sustainability are less 
obvious and worthy of consideration given the perceptions shared by one respondent who comes from a community affected by the Mackenzie Gas Project.

Caught in the fray is adult education. As a traditional bureaucratic apparatus of the state, Aurora College must navigate through a shifting socio-political terrain whose landscape contains new policy actors and a re-alignment of power. In this context, the college must respond and adapt in a manner that ensures its relevance and survival. Inevitably tensions arise, as shared by college respondents who intimated challenges of meeting community expectations tied to achieving hiring quotas set by industry and Aboriginal groups. These expectations have been hampered by a strong economy, combined with funding parameters that have politicized students along ethnic lines. Consequently, the college is faced with providing programming for a limited pool of suitable candidates.

\section{Northern State Formation}

Unlike the "modern state" from which Gramsci formulated his theories, northern state formation requires an analysis adjusted for cultural exigencies associated with Aboriginal political economy - namely a postcolonial transition from tribalism to neotribalism visavis capital accumulation and megaproject development on contested lands. Within this context, Gramscian conceptions of hegemony and state formation are portentous if we consider the "creation of alliances" through "the attempted incorporation of subordinate groups" and the "granting of concessions" which has taken place with respect to northern education, training and employment.

Current efforts underway in the NWT to promote skill-based training have resulted in adult education negotiating between incompatibilities of economic development and cultural preservation - a paradox contained within the goals of Aboriginal self-government (e.g. see Denendeh, 1984). While devolution and resource sharing agreements address the first two goals of self-government (land claims and economic development), the third goal - cultural preservation - while arguably implied in the first two, gets short shrifted with respect to program policy and planning, especially if we consider that the source of funding for trades-related programming (ASEP) is originally intended to provide "high quality, culturally relevant education for Aboriginal learners" (HRSDC, 2005).

This is not to say that the college is not providing opportunities in these areas such as self-governance (Scott, 2005), culture (e.g. "Traditional Arts Certificate" and Aboriginal languages), or infusing regular programs such as the nursing or the teacher education programs with cultural awareness. Yet it is the pace of development and shear magnitude of the projects underway that has arguably deformed holistic strategies for self-governance as articulated by Aboriginal groups.

A comparison of programs offered at Aurora College indicates trades-related programming has significantly increased in the past decade. In stark contrast to regional campuses (Fort Smith, Yellowknife, and Inuvik), smaller communities hosting a Community Learning Center, provide only Adult Basic Education and skill based training - programs that usually run for a few weeks at a time. While understandable, given the level of demand and resources available (both human and financial), this discrepancy 
requires people in smaller communities to relocate in order to broaden their education possibilities.

According to the Department of Education, Culture and Employment (Government of the Northwest Territories, n.d., p. 131), there were 769 full time equivalent students attending Aurora College in 1999 - a number that has dropped to 682 in 2005 (King, March 20, 2006) and 610 in 2006 (Dent, 2006). This drop has occurred despite an increase in population in the territory (approximately 2,000 people) and an increase in high school completion rates which have doubled for Aboriginal northerners within this time frame (Northwest Territories Bureau of Statistics, 2006). Consequently, claims made by some respondents that megaprojects act as a catalyst encouraging students to enter college programs is dubious.

Relegating education to technical training creates other problems for a society in transition. Reactive, quick-fix solutions to perceived labour shortages disguise low formal education levels, as signing groups become sinecures of megaprojects through preferential hiring practices. While the optics may appear impressive as seen in increased hiring of northern Aboriginals at mine sites (NWT \& Nunavut Chamber of Mines, p. 14), most employees are young men who occupy low-level positions (Northwest Territories Bureau of Statistics, 2005b) and must leave their community for extended periods of time to fulfill shift work. Meanwhile, the incentive to increase productivity through long-term capacity building is trumped by an elite financially compensated and motivated by the passive collection of rent and resource royalties.

Finally, marketization of education has contributed towards regional globalization as people continue to vacate small communities in favour for larger centers (Northwest Territories Bureau of Statistics, 2006). This shift is promoted by discrepancy in course offerings between regional campuses and communities. By considering implications these pressures have on small communities, their long-term viability comes into question as the only work available outside of government jobs is based on the short-term boom and bust cycle of non-renewable resource extraction industries. As the workforce becomes more transient, more people will leave small communities, completing what arguably began in the 1950s when Aboriginal people were coerced off the land through family allowance credits and government welfare - thus accomplishing the project of state formation.

\section{Future Research}

While the original intent of the inquiry was to focus on college policy planners, it became rapidly evident that a more nuanced analysis required understanding perceptions of those on the receiving end of such policy. Although one individual from a community directly impacted by megaproject development was able to provide valuable perspectives, further insights and analysis from members of Aboriginal communities was needed. An emphasis on gaining perceptions from policy planners may have inadvertently contributed towards the status quo which the inquiry set-out to critically appraise.

Considering limitations of the current study, further research endeavouring to understand implications of policy for those it is intended for is should be useful. In particular, a focus on northern Aboriginal communities in the NWT is needed. Tied to this is the manner in which training and employment agreements reached by Aboriginal 
governments and industry are affecting local aspirations and notions of community sustainability.

\section{References}

Arctic Human Development Report (2004). Stefansson Arctic Institute. Retrieved May, 25,2006 , from http://www.svs.is/AHDR/AHDR\%20chapters/AHDR first $\% 2012$ pages.pdf

Burleton, D. (2003, December). Canada's Northwest Territories - Can gas and gems bring sustained growth to the North? Toronto Dominion Bank Special Report. Retrieved October 17, 2005, from http://www.td.com/economics/special/nwt03.jsp

Cunningham, P. (2000). A sociology of adult education. In E. Hayes \& A. Wilson (Eds.), Handbook of adult and continuing education (pp. 573-590). San Francisco: Jossey-Bass.

Denendeh, a Dene celebration. (1984). Yellowknife, NT: Dene Nation.

Dent, C. (2006). Member's Statements. Retrieved on October 3, 2006 from http://www.charlesdent.com/sessions/statements/summer2006/index.htm

Government of the Northwest Territories. (n.d.). Learning and success in the $21^{\text {st }}$ century, Aurora College, corporate plan 2001-2005. Fort Smith, NWT: Cascade Graphics.

Gramsci, A. (1992/1971). State and civil society. In Q. Hoare and G. Nowell Smith (Eds. \& Trans.), Selections from the prison notebooks of Antonio Gramsci. New York: International Publishers. (Original work published 1971)

Green, A. (1990). Education and state formation. Hampshire, UK: The Macmillan Press.

Huberman, A., \& Miles, M. (1998). Data management and analysis methods. In K. Denzin \& Y. Lincoln (Eds.), Collecting and interpreting qualitative materials (pp. 179-210). London: Sage Publications.

Human Resources and Social Development Canada (HRSDC).(2005, February 3). Mine training society, Retrieved August 23, 2005, from http://www.hrsdc.gc.ca/en/cs/comm/hrsd/news/2005/050203b.shtml\#101

King, J. (2006, February 27). Discord exposed within Gwich'in Nation. News North, p. A13.

King, J. (2006, March 20). Meeting NWT needs today and tomorrow. News North, p. 14.

Loreen, D. (2005, October 17). Delta fears for gas future. News North, p. A13.

Mackenzie Gas Project (n.d.). Retrieved January 6, 2008, from http://www.mackenziegasproject.com/

Mayo, P. (1999). Introduction [Antonio Gramsci, Paulo Freire and Adult Education]. In P. Mayo (Ed.), Gramsci, Freire \& adult education: Possibilities for transformative action (pp.1-34). London: Zed Books.

Murphy, M. (2001). The politics of adult education: State, economy and civil society. International Journal of Lifelong Education, 20(5), 345-360.

Neary, D. (2006, June). Tlicho assumes power. News North [Special Edition: Opportunities North], p. A35.

Northwest Territories Bureau of Statistics. (2005a). Community population estimates by ethnicity. Retrieved June 20, 2006, from 
http://www.stats.gov.nt.ca/Statinfo/Demographics/population/est_data/commethni city.xls

Northwest Territories Bureau of Statistics. (2005b) Employment characteristics, in the NWT diamond industry. Retrieved June 20, 2006, from http://www.stats.gov.nt.ca/Statinfo/Labour/Labour\%20Market\%20Presentation/E CE\%20No2.ppt

Northwest Territories Bureau of Statistics. (2006, May). 2006 NWT socio-economic scan Retrieved June 23, 2006, from http://www.stats.gov.nt.ca/Statinfo/Generalstats/Scan/Scan_2006.pdf

NWT \& Nunavut Chamber of Mines. (n.d.). Sustainable economies: Aboriginal participation in the Northwest Territories mining industry 1990 - 2004. Retrieved October 21, 2006 from

http://www.miningnorth.com/docs/Aboriginal\%20Participation\%202005\%20(2).p df

Scott, L. (2005, November 16). Aurora College has new partner. Yellowknifer, p. A19. 